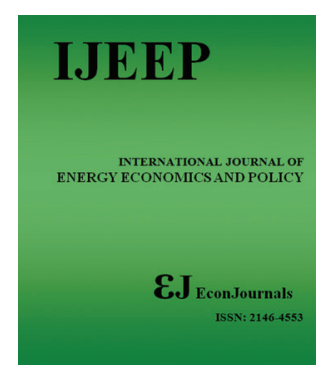

International Journal of Energy Economics and
Policy

ISSN: $2146-4553$

available at http: www.econjournals.com

International Journal of Energy Economics and Policy, 2019, 9(5), 207-215.

\title{
Green Energy Project’s Efficiency: A Cross-industry Evaluation
}

\author{
Assel K. Kozhakhmetova ${ }^{1 *}$, Kenzhebek T. Gabdullin ${ }^{2}$, Duissekul A. Kunanbayeva ${ }^{1}$, \\ Samal K. Tazhiyeva ${ }^{1}$, Renata E. Kydaybergenova ${ }^{2}$
}

${ }^{1}$ Department of Management and Marketing, Al-Farabi Kazakh National University, High School of Economics and Business, Almaty, Kazakhstan, ${ }^{2}$ Al-Farabi Kazakh National University, Faculty of Oriental studies, Almaty, Kazakhstan.

*Email: aselekdream@gmail.com

Received: 14 May 2019

Accepted: 15 July 2019

DOI: https://doi.org/10.32479/ijeep.8137

\begin{abstract}
Renewable energy attracts wide attention of world due to high importance and relevance. The study is devoted to this topic and aims to identify critical Project Management (PM) (further PM) knowledge areas those affect efficiency of green energy project, and to reveal PM tools those increase an efficiency. The study investigates 253 high-tech projects from Kazakhstan and compares green energy projects with projects from other industries like Information technologies (further IT), nanotechnologies and communications. Authors use PM Planning Quality (PMPQ) (further PMPQ) model for measuring the efficiency of these projects and for identifying critical factors of efficiency. Results show that IT projects have highest level of efficiency (cost overrun - 12,2\%, schedule overrun $-2,8 \%$, project performance $-8,8$ ), when green energy projects show average level of efficiency (cost overrun $-45,13 \%$, schedule overrun $-6,2 \%$, project performance $-7,5$ ). Research findings link these results with use intensity of PM processes. Project efficiency evaluation has also revealed critical knowledge areas for green energy projects like project schedule management, communication management, risk and quality management. Thus, authors have suggested tools and techniques from revealed knowledge areas for improving efficiency of project.
\end{abstract}

Keywords: Green Energy Project, Project Efficiency, Project Management, Project Planning, Kazakhstan JEL Classifications: C39, O21, Q20, Q42

\section{INTRODUCTION}

Renewable sources of energy have been the point of interest in the world due to climate changes and the inevitable depletion of finite resources such as coal and oil (Heng, 2017). Using biomass and coal in simple stoves produces substantial indoor air pollution and contributes significantly to the total burden of ill health (Kerimray, 2017). Moreover, competition for energy and resources is rapidly growing and affecting political life and economies of many countries (Ebel and Menon, 2000). We assume that one of the factors exacerbating this problem is rapidly growing level of energy consumption. Since the primary energy consumption growth averaged $2.2 \%$ in 2017 , up from $1.2 \%$ last year and the fastest since 2013 (BP, 2018) and projected to grow every year (Institute of Energy Economics Japan Outlook, 2019).
Energy demand in world countries will increase more and more in line with their economic development and living standard improvement, since indicating energy is required for economic development (Institute of Energy Economics Japan Outlook, 2019; Mukhtarova and Kozhakhmetova, 2017; Magazzino, 2017). For example, between 1999 and 2015, primary energy consumption grew from 26.92 to 91.08 Mtoe (International Energy Agency, 2017 ) and global energy demand grew by $2.2 \%$ in 2017 , up from $1.2 \%$ last year and above its 10 -year average of $1.7 \%$. Therefore, renewable energy and energy efficiency are urgent topics for nowadays.

Being the ninth largest country in the world, Kazakhstan is endowed with a large territory and vast natural resources such as oil, gas, uranium and copper (Orazgaliyev, 2018). But future population growth and urbanization together with fast GDP growth 
is likely to result in increased demand for energy, food and water (Karatayev et al., 2017; Mukhtarova et al., 2018). Moreover, experts and ecologists alarm us about the global climate change consequences such as lack of water, drought, desertification that might happen within 20-30 years in Kazakhstan. Therefore, issues of providing and developing renewable energy are relevant for most world`s countries.

Despite high interest of scholars and existence of vast studies related to renewable energy, a limitation of the relevant literature, there are lack of researches devoted to green energy projects efficiency. Moreover, few studies have considered the impact of Project Management (PM) practices on green energy projects efficiency.

The study investigates green energy projects efficiency level and critical factors that affect project efficiency from the viewpoint of PM. Authors suggest a model that aimed to identify specific knowledge areas of PM which affect efficiency of green energy projects. The objective of this study is to identify critical PM knowledge areas those affect green energy project efficiency and to reveal PM tools which increase green energy projects efficiency.

The structure of paper includes the following sections. First section introduces research relevance and research question. The second section presents theoretical background of the study. The third section explains the research model and data collection process. The fourth section contains discussion and analysis of empirical results. The fifth section concludes the study.

\section{LITERATURE REVIEW}

The study considers green energy projects implemented in Kazakhstan, therefore literature review devotes to current development and potential of renewable energy in chosen country and analyzes existed measurements of project efficiency.

\subsection{Green Energy Potential of Kazakhstan}

Energy is the most abundant and valuable natural resource of Central Asia and northwest China. And Kazakhstan has large reserves of oil and coal (Dorian, 2006). Kazakhstan is rich in natural resources including coal, oil, natural gas and uranium and has significant renewable potential from wind, solar, hydro-power and biomass. In spite of this, the country is currently dependent upon fossil fuels for power generation. Coal-fired plants account for $75 \%$ of total power generation leading to concerns over greenhouse gas emissions and impacts on human health and the environment (Karatayev and Clarke, 2016). The remaining generation is met by hydropower (around $10 \%$ ), while renewables, such as wind and solar, currently have a minimal contribution to the energy system $(<1 \%)$ (National Energy Report, 2017). These facts show that the energy sector of Kazakhstan is greatly affected by the abundance of fossil fuel reserves in the country.

Moreover, Kazakhstan is newly industrialized country with rapid growing economy (Smagulova et al., 2018). Due to fact that economic growth supposes high level of energy consumption, energy consuming in Kazakhstan may forecasted to grow annually.
Thus, according to results of Statistical review of world energy (BP, 2018), Kazakhstan have consumed $0,6 \%$ of world's total primary energy in 2018 which is $1,8 \%$ more than in 2017. As practice shows, such rapidly growing level of energy consumption influences on competition for energy resources.

Competition for energy resources in Kazakhstan, and more broadly in the Caspian region and Central Asia, received adequate attention in the scholarly literature (Akiner, 2004; Dorian, 2006; Ebel and Menon, 2000). For example, Ebel and Menon (2000) examine relationship between competition for energy resources and the propensity for conflict in the Caspian region. They mentioned significance of Caspian oil and gas to the global market and necessity of renewable energy production in these regions. They found significant new findings concerning the impact of energy wealth on the political life and economies of Azerbaijan, Kazakhstan, and Turkmenistan.

Despite an energy mix dominated by fossil fuels there is an increasing interest in renewable alternatives due to their environmental sustainability and economic development potential (Srebotnik and Hardi, 2011). Thus, another group of scholars investigate green energy potential of Kazakhstan and reveals many barriers for development of such projects (Karatayev et al., 2016; Mukhtarova et al., 2016; Bekturganova et al., 2019; Karatayev and Clarke, 2014). For example, Karatayev et al. (2016) assume that major contributors to replacing fossil fuel based energy services are likely to be wind power and solar energy technologies, with biomass and hydro energy sources likely to play a lesser role. They argue that despite the abundance of solar and wind power potential in the country, these sources of energy are not widely used due to the lack of appropriate infrastructure and of an appropriate institutional and legislative framework (Karatayev and Clarke, 2016).

Karatayev and Clarke (2014) explains reason of these difficulties through analysis of barriers for green energy development in Kazakhstan. They derive financial and institutional barriers. Financial barriers are low price of electricity in the country, difficulties in attracting foreign investment and a lack of access to credit for both consumers and investors. Institutional barriers include the absence of a clear national program for renewable energy development, a lack of specific action plans and instruments, a lack of concrete competitive legislation and regulation relating to the newly developed renewable energy market (Karatayev and Clarke, 2014). Another group of scholars lead by Assembayeva et al. (2017) found new ways of solving mentioned above problems through storage technologies of renewable energy integration in Kazakhstan. Model proposed by them determines the optimal way of implementation of energy storage technologies and renewable energy sources. Mukhtarova et al. (2019) proposed to assign green energy projects to high-tech projects and to use PM tools for providing efficiency of such projects. Further Shoaib and Ariaratnam (2016) conducted very interesting and deep research that reviewed local potential renewable resources and established assessment framework for prioritizing these resources in Afganistan. Their research model shows that renewable energy projects influence on socioeconomic development of the country. 
Moreover, according to Karatayev et al. (2017), there is also significant potential to produce electricity and heat from agricultural and forestry waste. Apart from agricultural and forestry wastes, the cities and regional centers in Kazakhstan annually produce 3.4 million tonnes of municipal wastes which could partly be used for waste to electricity generation (Energy Report from Ministry of Energy RK, Waste Management Department, 2017).

Literature analysis reveals supportive activities of government directed to green energy development in Kazakhstan. Thus, local government intends to construct 11 small-scale hydropower stations by 2020 . The Green Economy 2050 Strategy, which provides an overall framework for the low-carbon energy transition, also outlines an increase in biofuel production, with three biodiesel plants to be constructed in the North and South Kazakhstan. Regarding renewable energy, the immediate target is to increase the share to $6 \%$ of the total energy mix by 2025 and to $50 \%$ by 2050 (National Database, 2018). According to the Roadmap for the Development of Alternative Energy for 2012-2030 (Directive No 068 of February 24, 2017), the country intends to install 106 renewable energy projects with more than $3000 \mathrm{MW}$ of renewable energy capacity by 2020 .

\subsection{Green Energy Project's Efficiency}

Green energy are, ideally, clean, affordable, of minimum environment impacts, and are considered to be the only answer to the sustainably of humanity in the foreseeable future (Zhang and Guo, 2017). Currently global market of green products and services makes $\$ 546$ billion (Diyar et al., 2014). Many countries are making efforts for promoting the adoption of new and renewable energy sources (Christiansen, 2002). These facts suppose an existence of global market of green energy projects and studies focused on development of such projects.

According to a rough statistic by Web of Science, more than 200,000 publications were reported in the past five years in scopes related with wind and solar energy, and electrochemical processes (Zhang and Guo, 2017). But literature review reveals lack of studies devoted to green energy projects efficiency (Maqbool, 2018) and absence of attention on PM tools that increase efficiency and success of such projects. A number of studies confirm that the project efficiency and success rate increases if PM methods are used (Patanakul et al., 2010; Lappe and Spang, 2014).

Literature reveals that project efficiency is measured in a variety of ways. Most of scholars link project efficiency with project success. There are many researchers who conducted different researches in order to find out various critical success factors for the project success (Kerzner, 1987; Pinto and Slevin, 1989; Zwikael and Globerson, 2006; Müller and Turner, 2007).

For example, Turner and Zolin (2012) suggest project efficiency is important to success, because if the project is completed late and over budget it will be more difficult for it to be a business success. Shenhar et al. (1997) distinguish three traditional dimensions of project efficiency - time, budget, and scope. They assume that sope has the largest role, because it also has an impact on the customer satisfaction. Serrador and Turner (2014) support this statement and propose to measure project efficiency through cost, time and scope.
Prabhakar (2008) argues that schedule and budget performance alone are considered inadequate as measures of project success, they are dimensions of project efficiency. Further Shenhar and Dvir (2007) support this idea and identify efficiency as one of the five dimensions of project success. They state that project efficiency consists meeting schedule goal and meeting budget goal. Zwikael and Globerson (2006) using data collected from 280 project managers showed aspects of project success and derived scope and cost as components of project efficiency. Our study bases on this approach which measures green energy project efficiency by cost budgeting and time scheduling.

\section{RESEARCH CONFIGURATION}

\subsection{Research Model}

The study uses model that based on PM Planning Quality (PMPQ) model suggested by Zwikael and Globerson (2004) and Organizational Maturity model. Because it's based on an acceptable PMBOK (2004) and is found reliable. The model is used for investigation of relation between PM knowledge areas and green energy projects' efficiency. There are two variables where PM knowledge areas are independent variable and project efficiency is dependent variable. Thus, the model measures which PM knowledge areas have higher impact on green energy projects efficiency. Authors measure this impact through use intensity of PM planning processes those exist in each PM knowledge area. For example, project integration management is carried out by performing particular planning processes (develop PM plan). On the other hand, project scope management requires performing another planning processes (define scope, create work breakdown structure) etc. Thus, in alignment with the research objective, the research model that shown in Figure 1 aims to examine influence of 16 project planning processes on three efficiency dimensions like cost overrun, schedule overrun and project performance (Figure 1).

As depicted in Figure 1, we can measure influence of PM knowledge areas on green energy projects efficiency by using this model. An average use intensity of planning processes presented by "PMPQ index. Authors found that PMPQ index highly correlates with project efficiency which is measured by cost and schedule overrun. Table 1 presents 24 planning processes which constitute knowledge areas. The study uses 16 of them.

\subsection{Reliability and Validity}

Reliability of model was checked by using Cronbach alpha analysis that performed on the efficiency measures. The Cronbach alpha coefficient is a number that ranges from 0 to 1 ; a value of 1 indicates that the measure has perfect reliability, whereas a value of 0 indicates that the measure is not reliable and variations are due to random error (Cronbach, 1951). In general, an alpha value of 0.9 is required for practical decision-making situations, whereas a value of 0.7 is considered to be sufficient for research purposes (Nunnally, 1978).

Project efficiency is measured by three items. All measures showed a high Cronbach alpha score, which means that they are correlated. The results of the Cronbach's alpha testing let us to assume that the items chosen for measuring project efficiency were valid and reliable for this study. Because all variables show an alpha 
Figure 1: Research design

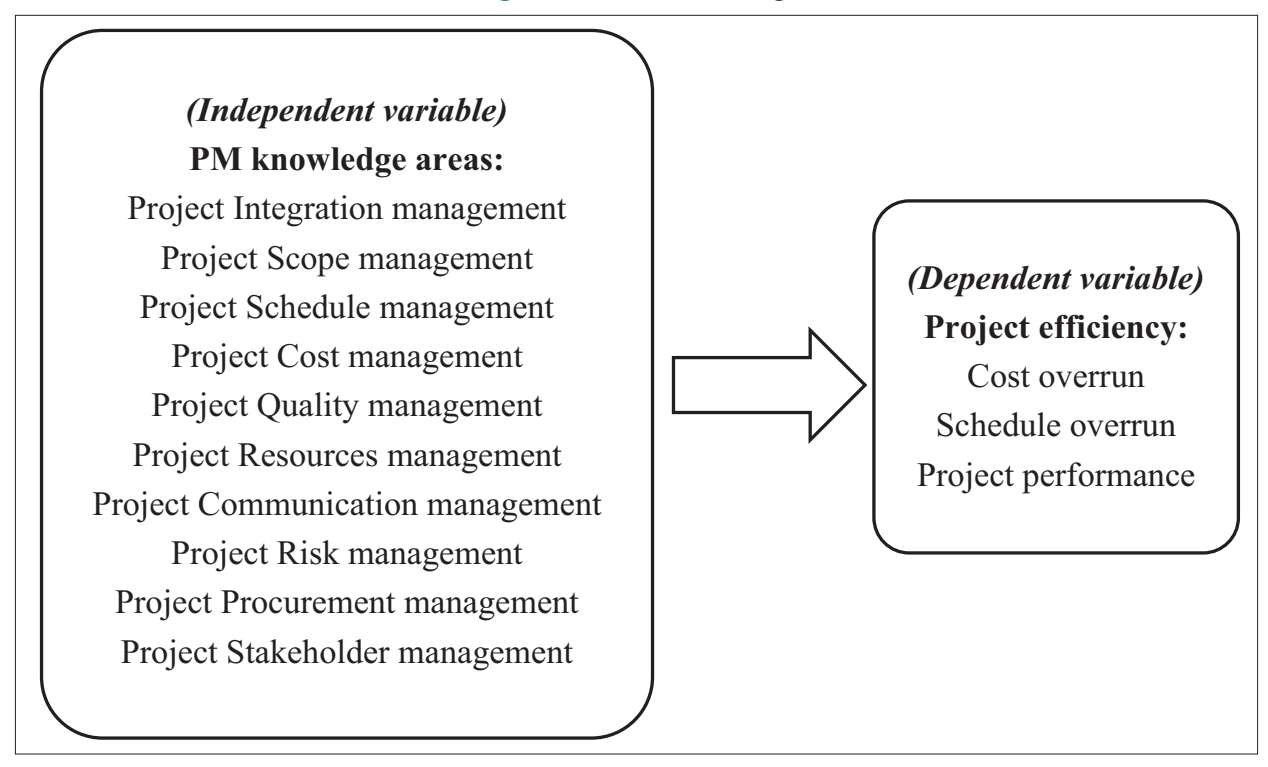

Table 1: The linkage between PM knowledge areas and planning processes

\begin{tabular}{|c|c|}
\hline PM knowledge areas & 24 planning processes \\
\hline $\begin{array}{l}\text { Project integration } \\
\text { management }\end{array}$ & Develop PM plan \\
\hline \multirow{4}{*}{$\begin{array}{l}\text { Project scope } \\
\text { management }\end{array}$} & Scope planning \\
\hline & Collect requirements \\
\hline & Define scope \\
\hline & Create work breakdown structure (WBS) \\
\hline \multirow{6}{*}{$\begin{array}{l}\text { Project schedule } \\
\text { management }\end{array}$} & Plan schedule management \\
\hline & Define activities \\
\hline & Sequence activities \\
\hline & Estimate activity resources \\
\hline & Estimate activity durations \\
\hline & Develop schedule \\
\hline \multirow[t]{3}{*}{ Project cost management } & Plan cost management \\
\hline & Estimate costs \\
\hline & Determine budget \\
\hline $\begin{array}{l}\text { Project quality } \\
\text { management }\end{array}$ & Plan quality management \\
\hline $\begin{array}{l}\text { Project human resources } \\
\text { management }\end{array}$ & Plan human resource management \\
\hline $\begin{array}{l}\text { Project communication } \\
\text { management }\end{array}$ & Communications management planning \\
\hline \multirow[t]{5}{*}{ Project risk management } & Risk management planning \\
\hline & Identify risks \\
\hline & Perform qualitative risk analysis \\
\hline & Perform quantitative risk analysis \\
\hline & Plan risk responses \\
\hline $\begin{array}{l}\text { Project procurement } \\
\text { management }\end{array}$ & Procurement management planning \\
\hline $\begin{array}{l}\text { Project stakeholder } \\
\text { management }\end{array}$ & Plan stakeholder management \\
\hline
\end{tabular}

*Source: PMBOK GUIDE, 2013. PM: Project management

score $>0.90$. This fact proves the assumption that all variables are interrelated. Moreover, authors found that all results are significant with $P$ values under 0,001 Table 2.

As depicted on Table 2, all dimensions of efficiency show significant correlation, and this fact proves idea that research results are valid.

\subsection{Sample and Data Collection}

The survey prepared for building research model. It includes data about use intensity of 16 planning processes and data about cost and schedule overruns of projects. The data was collected from project managers who run projects in the sphere of green energy, nanotechnology, communications and information technologies (further IT) during 2018-2019. Authors cover additional industries in this research for comparing green energy projects efficiency with other projects. The questionnaire can be seen in appendix A.

Questionnaires that had at least $85 \%$ of completed data were included to analysis in order to increase the reliability of gathered data. Finally, 253 questionnaires remained for analysis, including 59 from the green energy industry of Kazakhstan.

As Table 3 shows, average percentage of valid questionnaires from each industry are $25 \%$. We decide that it's quite enough for adequate comparison of chosen industries.

Project managers participated in the survey were asked about extent of use 16 planning processes. They evaluate it through scale ranging from 1 to 5 Likert scale, where 1 is worst result and 5 is best result. Further project supervisors were asked about cost and schedule overrun which evaluated by percentage from planned level. For example, project supervisor plans to spend 5 million dollars for project, but exceeds the budget to 7, 5 million dollars. Cost overrun will be $50 \%$. Then project managers were asked to evaluate project performance level from 1 to 10 (from low to high level).

\section{RESULTS AND DISCUSSION}

\subsection{Project Efficiency Analysis}

The study compares efficiency dimensions of green energy projects with projects from other industries (Figure 2).

As depicted in Figure 2, the most efficient projects are IT projects. Because they have the lowest level of cost $(12,2 \%)$ and schedule 
Table 2: Validity test for the data

\begin{tabular}{lccc} 
Efficiency measure & $\mathbf{R}$ & P value & Meaning \\
Cost overrun & 0.61 & $<0.001$ & Average correlation, high significance \\
Schedule overrun & 0.67 & $<0.001$ & Average correlation, high significance \\
Project performance & 0.91 & $<0.001$ & Very high correlation, high significance \\
\hline
\end{tabular}

Table 3: Research sample details

\begin{tabular}{lccc} 
Project type & Total number & Number of valid questionnaires & Percentage of valid questionnaires, \% \\
Green energy project & 65 & 59 & 23,3 \\
Nanotechnology project & 59 & 54 & 21.3 \\
Communications & 79 & 69 & 27,3 \\
IT project & 77 & 71 & 28,1 \\
Total & 280 & 253 & 100 \\
\hline
\end{tabular}

IT: Information technologies

Figure 2: Projects` efficiency level according to industry

\begin{tabular}{|l|l|l|l|}
\hline & \\
\hline
\end{tabular}

overrun $(2,8 \%)$, and the highest level of technical performance $(8,8)$. As we explained before, projects those significantly exceed planned cost and schedule are lose the efficiency. These findings let us to assume that IT-projects more efficient than others due to the fact, that project managers from this area often use schedule and cost PM knowledge areas. In addition, it's worldwide known that PM tools actively used in the area of IT (Zwikael, 2009; Cerdeiral and Santos, 2019).

Nanotechnology projects show worst results. Because these projects exceed planned cost for $91,9 \%$ and schedule for $6,6 \%$. In addition, the level of technical performance is 7,5 (one of the lowest). This may be explained by complexity and expose to risk of such kind of projects. Moreover, this may be due to the rare use of PM during project implementation. Next part of this section that dedicated to PM processes` performance may check this assumption.

Efficiency level of green energy projects better than nanotechnology projects. Green energy projects show better schedule overrun
$(6,2 \%)$ after IT projects. But project performance level is low $(7,5)$. These facts show that green energy projects of our country are not so efficient and we should make efforts for improving this situation. One of the ways of implementing these efforts is using PM tools and techniques. Further, we concentrate on processes of PM that affect project efficiency.

\subsection{PM Processes Analysis}

Data gathered from project managers about using intensity of planning processes gives total vision about projects ' planning quality in chosen industries. Also data analysis presents which project knowledge areas often performed by each industry`s project managers. This information depicted in Table 4.

Table 4 shows essential differences between chosen industries in performing PM planning processes. IT project managers perform cost budgeting, cost estimating, schedule, quality and communication processes better than three other countries. These findings explain best results of IT projects during measuring three efficiency 
Table 4: Link between PM processes and project efficiency

\begin{tabular}{|c|c|c|c|c|c|}
\hline $\begin{array}{l}\text { Planning } \\
\text { processes }\end{array}$ & $\begin{array}{c}\text { PMPQ index/Green } \\
\text { energy projects }(n=59)\end{array}$ & $\begin{array}{l}\text { PMPQ index/IT } \\
\text { projects }(n=54)\end{array}$ & $\begin{array}{c}\text { PMPQ index/Nanotech. } \\
\text { projects }(\mathrm{n}=69)\end{array}$ & $\begin{array}{c}\text { PMPQ index/Communication } \\
\text { projects }(n=71)\end{array}$ & $\begin{array}{c}\text { P values } \\
\text { (for green energy) }\end{array}$ \\
\hline $\begin{array}{l}\text { Activity } \\
\text { definition }\end{array}$ & 3.6 & 4.2 & 3.5 & 3.7 & $0.001 * *$ \\
\hline Staff acquisition & 3.3 & 3.7 & 3.2 & 3.4 & 0.315 \\
\hline $\begin{array}{l}\text { Project plan } \\
\text { development }\end{array}$ & 3.6 & 4.1 & 3.9 & 3.9 & 0.121 \\
\hline $\begin{array}{l}\text { Resource } \\
\text { planning }\end{array}$ & 3.7 & 3.9 & 3.6 & 3.8 & 0.122 \\
\hline $\begin{array}{l}\text { Activity duration } \\
\text { estimating }\end{array}$ & 4.0 & 4.0 & 3.8 & 3.9 & $0.035^{*}$ \\
\hline Scope planning & 3.6 & 4.2 & 3.3 & 3.8 & 0.072 \\
\hline $\begin{array}{l}\text { Procurement } \\
\text { planning }\end{array}$ & 2.9 & 3.5 & 2.8 & 3.0 & 0.350 \\
\hline $\begin{array}{l}\text { Organizational } \\
\text { planning }\end{array}$ & 3.3 & 3.9 & 3.2 & 3.6 & 0.256 \\
\hline $\begin{array}{l}\text { Risk } \\
\text { management } \\
\text { planning }\end{array}$ & 2.5 & 2.8 & 2.2 & 2.7 & $0.001 *$ \\
\hline Quality planning & 2.6 & 3.0 & 2.5 & 2.8 & $0.001 *$ \\
\hline $\begin{array}{l}\text { Activity } \\
\text { sequencing }\end{array}$ & 3.3 & 3.6 & 3.2 & 3.4 & 0.372 \\
\hline $\begin{array}{l}\text { Schedule } \\
\text { development }\end{array}$ & 3.8 & 4.1 & 3.7 & 3.8 & 0.312 \\
\hline Scope definition & 3.2 & 3.8 & 3.1 & 3.3 & 0.125 \\
\hline Cost budgeting & 3.3 & 3.4 & 3.2 & 3.3 & 0.198 \\
\hline $\begin{array}{l}\text { Communication } \\
\text { planning }\end{array}$ & 2.6 & 2.9 & 2.4 & 2.7 & $0.001 * *$ \\
\hline Cost estimating & 3.8 & 4.1 & 3.5 & 3.9 & $0.001 * *$ \\
\hline
\end{tabular}

${ }^{*} \mathrm{P} \leq 0.05,{ }^{*} \mathrm{P} \leq 0.001$ (High significance)

Table 5: Basic processes those affect green energy project efficiency

\begin{tabular}{lccc} 
Planning processes & PMPQ index/Green energy projects $(\mathbf{n = 5 9 )}$ & P values (for green energy) & Knowledge area \\
Activity definition & 3.6 & $0.001^{* *}$ & Project schedule \\
Activity duration estimating & 4.0 & $0.035^{*}$ & management \\
Risk management planning & 2.5 & $0.001^{*}$ & Project risk management \\
Quality planning & 2.6 & $0.001^{*}$ & Project quality management \\
Communication planning & 2.6 & $0.001^{* *}$ & Project Communication \\
& & & management \\
\hline
\end{tabular}

$* \mathrm{P} \leq 0.05, * * \mathrm{P} \leq 0.001$

dimensions as cost, schedule overrun and project performance. Nanotechnology projects PMPQ overall index is lower than all four projects. It means that managers who run nanotechnology projects make little use of PM tools. These results let to approve the statement that performing PM processes increase project efficiency.

Managers who run green energy projects pay more attention on activity duration estimating, schedule development and cost estimating. This can be explained by the fact that these processes are components of "Golden triangle" (cost, schedule, quality) that well-known and often used by managers from all over the world. In addition, least used processes of PM are risk management, quality planning and communication planning. We should note that the use of these processes are very important and necessary for projects those are implemented through using high-technologies, like production of renewable energy.

Further, we analyze critical PM processes and knowledge areas those highly affect green energy project efficiency. We calculate this relation by using multivariance regression (Table 5).
As Table 5 shows, there are 5 processes from 4 knowledge areas those strongly affect green energy project efficiency. We may state that using these knowledge areas increase the efficiency of investigated projects, because of high level of $\mathrm{P}$ value. Project schedule management and project communication management have highest impact on green energy projects efficiency. Moreover, project risk management and quality management are critical knowledge areas for green energy projects too. These findings let us to suggest tools and techniques from revealed 4 knowledge areas for improving efficiency of project. For instance, if project quality management is critical for investigated projects, project managers should intensively use PM tools of quality like Quality Inspection Management method, Pareto Chart, Cause and Effect Diagram, Total Quality Management system, etc. On the other hand, green energy project efficiency depends on using PM risk tools like risk prevention, reduction of potential losses, insurance risk transfer, impact on source of risk and so on. Moreover, the next list of PM tools from schedule management and communication management may be used for increasing an efficiency of green energy projects: Gant Chart, Planning 
and Prioritization technique, staff motivation, modern IT tools, permanent feedback system, etc.

\section{CONCLUSION}

The importance of green energy projects implementation has rapidly increased in the last years due to high interest of scientist and entire society in renewable energy.

Comparing 253 projects from high-tech industry, this study has revealed that green energy projects have average level of efficiency and average score in use PM processes. The best results in efficiency of IT projects were linked with high score in using PM processes. And as for nanotechnology, poor use of PM reflected in the low level efficiency. Therefore, study assumes that use intensity of PM processes increase the efficiency of green energy projects.

Project efficiency evaluation has also revealed critical processes for green energy projects. They are: "Activity definition," "Activity duration estimating," "Risk management planning," "Quality planning," "Communication planning." The study has also derived 4 main knowledge areas those significantly affect green energy project efficiency: Project schedule management, communication management, risk and quality management. Study states that using these knowledge areas increase the efficiency of investigated projects, because of high level of $\mathrm{P}$ value. Thus, authors suggest tools and techniques from revealed knowledge areas for improving efficiency of project. Project managers may find these tools from each critical knowledge areas those described in PMBOK Guide (2013).

Current study has also identified weaknesses of green energy PM. Results show that project managers don't pay enough attention on significant tools of PM like risk management, quality and communication planning.

This study contributes to PM knowledge by revealing specific PM processes for renewable energy industry. Research results give more practical tools for project managers from this area and additional knowledge for scholars who investigate this topic.

Finally, the study contributes to the current body of knowledge in the next directions:

- It identifies critical PM processes those affect green energy project efficiency;

- It makes specific recommendations for managing green energy projects through tools of PM knowledge areas;

- It shows specific critical planning processes those can be used during decision making;

- It allows project managers better executing a green energy projects.

Limitations of the study is that research focuses only on projects from Kazakhstan. Future research should be expanded by exploring other countries. Moreover, future research may increase a sample size, because this study investigates only 253 projects. Another limitation is that the study focuses only on planning phase of project. Future studies may cover another phases of PM.

\section{REFERENCES}

Akiner, S. (2004), The Caspian: Politics, Energy and Security. London: Routledge.

Assembayeva, M., Zhakiyev, N., Akhmetbekov, Y. (2017), Impact of storage technologies on renewable energy integration in Kazakhstan. Materials Today: Proceedings, 4, 4512-4523.

Bekturganova, M., Satybaldin, A., Yessekina, B. (2019), Conceptual framework for the formation of low-carbon development: Kazakhstan's experience. International Journal of Energy Economics and Policy, 9(1), 48-56.

BP. (2018), Statistical Review of World Energy. $67^{\text {th }}$ ed. New York: Energy Council.

Cerdeiral, C.T., Santos, G. (2019), Software project management in high maturity: A systematic literature mapping. Journal of Systems and Software, 148, 56-87.

Christiansen, A. (2002), New renewable energy developments and the climate change issue: A case study of Norwegian politics. Energy Policy, 30, 235-243.

Cronbach, L. (1951), Coefficient alpha and the internal structure of tests. Psychometrika, 16, 297-334.

Directive No 577. (2013), National Database of Legislations, Regulations, State Programs and Concepts in Kazakhstan. Available from: http:// www.online.zakon.kz.

Diyar, S., Akparova A., Toktabayev, A., Tyutunnikova, M. (2014), Green economy-innovation-based development of Kazakhstan. Procedia Social and Behavioral Sciences, 140, 695-699.

Dorian, J.P. (2006), Central Asia: A major emerging energy player in the $21^{\text {st }}$ century. Energy Policy, 34(5), 544-555.

Ebel, R., Menon, R. (2000), Energy and Conflict in Central Asia and the CAUCASUS. Available from: http://www.books.google.com.

Energy Report from Ministry of Energy RK, Waste Management Department. (2017), Municipal Waste in Kazakhstan. Available from: http:/www.energo.gov.kz.

Heng, L.K. (2017), Bio gas plant green energy from poultry wastes in Singapore. Energy Procedia, 143, 436-441.

Institute of Energy Economics Japan (IEEJ) Outlook. (2019). World Energy Statistics and Balances Data Service. Available from: http:// www.iea.org/statistics.

International Energy Agency. (2017), World Energy Statistics and Balances Data Service. Available from: http://www.iea.org/statistics.

Karatayev and Clarke. (2016), A review of current energy systems and green energy potential in Kazakhstan. Renewable and Sustainable Energy Reviews, 55, 491-504.

Karatayev, M., Clarke, M. (2014), Current energy resources in Kazakhstan and the future potential of renewables: A review. Energy Procedia, 59, 97-104.

Karatayev, M., Hall, S., Kalyuzhnova, Y., Clarke, M. (2016), Renewable energy technology uptake in Kazakhstan: Policy drivers and barriers in a transitional economy. Renewable and Sustainable Energy Reviews, 66, 120-136.

Karatayev, M., Rivotti, P., Mourao, Z.S., Konadu, D., Shah, N., Clarke M. (2017), The water-energy-food nexus in Kazakhstan: Challenges and opportunities. Energy Procedia, 125, 63-70.

Kerimray, A., Rojas-Solórzano, L., Torkmahalleh, M.A., Hopke, P.K., Gallachóir, B.P.Ó. (2017), Coal use for residential heating: Patterns, health implications and lessons learned. Energy for Sustainable Development, 40, 19-30.

Kerzner, H. (1987), In search of excellence in project management. J Systems Manage, 38(2), 30-40.

Lappe, M., Spang, K. (2014), Investment in project management are profitable: A case study-based analysis of the relationship between the costs and benefits of project management. International Journal 
of Project Management, 32(4), 603-612.

Magazzino, C. (2017), Renewable energy consumption-economic growth nexus in Italy. International Journal of Energy Economics and Policy, 7(6), 119-127.

Maqbool, R. (2018), Efficiency and effectiveness of factors affecting renewable energy projects; An empirical perspective. Energy, 158, 944-956.

Mukhtarova, K., Kozhakhmetova, A., Belgozhakyzy, M., Dosmbek, A., Barzhaksyyeva, A. (2019), High-tech entrepreneurship in developing countries. Academy of Entrepreneurship Journal, 25 (1), 1-10.

Mukhtarova, K., Ospanov, S., Sharapiyeva, M., Antoni, A. (2018), The evaluation of the efficiency of transport and logistics infrastructure of railway transport. Pomorstvo, 32 (1), 88-101.

Mukhtarova, K., Trifilova, A., Zhidebekkyzy, A. (2016), Commercialization of green technologies: An exploratory literature review. Journal of International Studies, 9(3), 75-87.

Mukhtarova, K.S., Kozhakhmetova, A.K. (2017), Statistical methods as a tool of high-tech products quality management. Bulletin of the National Academy of Sciences the Republic of Kazakhstan, 3, 243-250.

Müller, R., Turner, R. (2007), The influence of project managers on project success criteria and project success by type of project. European Management Journal, 25(4), 298-309.

National Database of RK. (2018), Available from: http://www.kndc.kz.

National Energy Report. (2017), Kazenergy Association. Available from: http://www.kazenergy.com.

Nunnally, J. (1978), Psychometric Theory. New York: McGraw-Hill.

Orazgaliyev, S. (2018), State intervention in Kazakhstan's energy sector: Nationalisation or participation? Journal of Eurasian Studies 9, 143-51.

Patanakul, P., Iewwongcharoen, B., Milosevic, D. (2010), An empirical study on the use of project management tools and techniques across project life-cycle and their impact on project success. Journal of General Management, 35(3), 41-65.

Pinto, J.K., Slevin, P.S (1989), Critical success factors in R and D projects. Research Technology Management, 32(1), 31-36.

PMBOK Guide. (2013), A Guide to the Project Management Body of Knowledge. $5^{\text {th }}$ ed. Pennsylvania, Newtown Square: PMBOK Guide.

PMBOK. (2004), A Guide to the Project Management Body of Knowledge: $4^{\text {th }}$ ed. Pennsylvania: Newtown Square.

Serrador, P., Turner, R. (2014), The Relationship between project success and project efficiency. Procedia Social and Behavioral Sciences, $119,75-84$.

Shenhar, A., Dvir, D. (2007), Reinventing Project Management: The Diamond Approach to Successful Growth and Innovation. Boston: Harvard Business Press.

Shenhar, A.J., Levy, O., Dvir, D. (1997), Mapping the dimensions of project success. Project Management Journal, 28(2), 5-9.

Shoaib, A., Ariaratnam, S. (2016), A study of socioeconomic impacts of renewable energy projects in Afghanistan. Procedia Engineering, $145,995-1003$.

Smagulova, S., Nurseiytova, G., Madjarova, R., Spankulova, L., Koptayeva, G., Dzhunusov, A., Omarkulova, M., Bikenova, A., Turekulova, A., Imashev, A. (2018), Entrepreneurship and investment environment in the central Asian transition countries: Case Kazakhstan. Academy of Entrepreneurship Journal, 4(24), 22-31.

Srebotnik, T., Hardi, P. (2011), Prospects for sustainable bioenergy production in selected former communist countries. Ecological Indicators, 11, 1009-1019.

Turner, R., Zolin, R. (2012), Forecasting success on large projects: Developing reliable scales to predict multiple perspectives by multiple stakeholders over multiple time frames. Project Management Journal, 43(5), 87-99.

Zhang, S., Guo, S. (2017), Green energy for green future. Green Energy and Environment, 2, 65.

Zwikael, O. (2009), Critical planning processes in construction projects. Construction Innovation, 9(4), 372-387.

Zwikael, O., Globerson, S. (2004), Evaluation the quality of project planning: A model and field results. International Journal of Production Research, 42, 1545-1556.

Zwikael, O., Globerson, S. (2006), Benchmarking of project planning and success in selected industries. Benchmarking: An International Journal, 13(6), 688-700. 


\section{APPENDIX A}

\section{Project planning assessment questionnaire}

Please indicate the most suitable answer for each planning product as it relates to the projects you are currently involved in, according to the following scale:

5- The product is always obtained.

4- The product is quite frequently obtained.

3 - The product is frequently obtained.

2- The product is seldom obtained.

1- The product is hardly ever obtained.

A. The product is irrelevant to the projects I am currently involved in

B. B- I do not know whether the product is obtained.

\begin{tabular}{|c|c|c|c|c|c|c|c|c|}
\hline No. & Planning product & Never & & & & Always & Irrelevant & Do not know \\
\hline \multicolumn{9}{|c|}{ Part A - planning processes } \\
\hline 1 & Project plan development & 1 & 2 & 3 & 4 & 5 & A & $\mathrm{B}$ \\
\hline 2 & Scope planning & 1 & 2 & 3 & 4 & 5 & A & $\mathrm{B}$ \\
\hline 3 & Scope definition & 1 & 2 & 3 & 4 & 5 & A & $\mathrm{B}$ \\
\hline 4 & Activity definition & 1 & 2 & 3 & 4 & 5 & A & $\mathrm{B}$ \\
\hline 5 & Activity sequencing & 1 & 2 & 3 & 4 & 5 & A & $\mathrm{B}$ \\
\hline 6 & Activity duration estimating & 1 & 2 & 3 & 4 & 5 & A & $\mathrm{B}$ \\
\hline 7 & Schedule development & 1 & 2 & 3 & 4 & 5 & A & $\mathrm{B}$ \\
\hline 8 & Resource planning & 1 & 2 & 3 & 4 & 5 & A & $\mathrm{B}$ \\
\hline 9 & Cost estimating & 1 & 2 & 3 & 4 & 5 & $\mathrm{~A}$ & $\mathrm{~B}$ \\
\hline 10 & Cost budgeting & 1 & 2 & 3 & 4 & 5 & A & $\mathrm{B}$ \\
\hline 11 & Quality planning & 1 & 2 & 3 & 4 & 5 & A & $\mathrm{B}$ \\
\hline 12 & Organizational planning & 1 & 2 & 3 & 4 & 5 & A & $\mathrm{B}$ \\
\hline 13 & Staff acquisition & 1 & 2 & 3 & 4 & 5 & $\mathrm{~A}$ & $\mathrm{~B}$ \\
\hline 14 & Communication planning & 1 & 2 & 3 & 4 & 5 & A & $\mathrm{B}$ \\
\hline 15 & Risk management planning & 1 & 2 & 3 & 4 & 5 & A & $\mathrm{B}$ \\
\hline 16 & Procurement planning & 1 & 2 & 3 & 4 & 5 & A & $\mathrm{B}$ \\
\hline
\end{tabular}

Please indicate the most suitable answer for each measurement according to exceeding percent from planned index

\begin{tabular}{lll} 
No. & Measure & $\%$ \\
1 & Cost overrun & \\
2 & Oschedule overrun & \\
\hline
\end{tabular}

Please indicate the most suitable answer according to the following scale

\begin{tabular}{lllllllllllc} 
No. & Measure & \multicolumn{1}{c}{ Low degree } & & High degree \\
1 & $\begin{array}{l}\text { Project } \\
\text { performance }\end{array}$ & 1 & 2 & 3 & 4 & 5 & 6 & 7 & 8 & 9 & 10 \\
\hline
\end{tabular}

